\title{
Combination on endophytic fungal as the Plant Growth-Promoting Fungi (PGPF) on cucumber (Cucumis sativus)
}

\author{
SYAMSIA SYAMSIA ${ }^{1, \bullet}$, ABUBAKAR IDHAN ${ }^{1}$, AMANDA PATAPPARI FIRMANSYAH ${ }^{1}$, \\ NOERFITRYANI NOERFITRYANI ${ }^{2}$, IRADHATULLAH RAHIM ${ }^{3}$, HENRY KESAULYA ${ }^{4}$, RAKHMAD ARMUS $^{5}$ \\ ${ }^{1}$ Department of Agrotechnology, Faculty of Agriculture, Universitas Muhammadiyah Makassar. J1. Sultan Alauddin No. 259, Makassar 90222, South \\ Sulawesi, Indonesia. `email: syamsiatayibe@unismuh.ac.id \\ ${ }^{2}$ Department of Agribusiness, Faculty of Agriculture, Universitas Muhammadiyah Makassar. Jl. Sultan Alauddin No. 259 Makassar 90222, South \\ Sulawesi, Indonesia \\ ${ }^{3}$ Department of Agrotechnology, Faculty of Agriculture, Animal Husbandry, and Fisheries, Universitas Muha mmadiyah Parepare. Jl. Jend. Ahmad Yani \\ Km 6., Parepare 91113, South Sulawesi, Indonesia \\ ${ }^{4}$ Department of Plant Breeding, Faculty of Agriculture, Universitas Pattimura. Jl. Ir. M. Putuhena, Kampus Poka, Ambon 97233, Maluku, Indonesia \\ ${ }^{5}$ Department of Environmental Engineering, Sekolah Tinggi Teknologi Nusantara Indonesia. Jl. Baruga Raya, Makassar 90234, South Sulawesi, \\ Indonesia
}

Manuscript received: 6 December 2020. Revision accepted: 9 February 2021

\begin{abstract}
Syamsia S, Idhan A, Firmansyah AP, Noerfitryani N, Rahim I, Kesaulya H, Armus R. 2021. Combination on endophytic fungal as the Plant Growth-Promoting Fungi (PGPF) on Cucumber (Cucumis sativus). Biodiversitas 22: 1194-1202. Endophytic fungi are known to stimulate plant growth by producing secondary metabolites, including phytohormones (IAA and Gibberellins), siderophore, phosphate-solubilizing metabolites. In this study, a total of six endophytic fungi were successfully isolated from local rice plants and showed different abilities in producing secondary metabolites, during single isolates testing. These six isolates were then combined to obtain 15 combinations for analysis, to determine the best combination for application as a plant growth promoter. Subsequently, each combination was tested for phytohormones (IAA, gibberellins) and siderophore (quantitatively)-producing activity, phosphate-solubilizing ability, and the effect on cucumber (Cucumis sativus L) plant growth. F13 showed activity in producing IAA and produced the highest gibberellin levels, while F1 exhibited the highest phosphate-solubilizing activity. In addition, F11 (Na-salicylate) and F1 (catechol) showed the highest siderophore activity, while a combination of F6, F8, F9, and F12 successfully increased plant height growth. Also, F4 increased the root growth, while the fresh weight of cucumber was increased by F8 treatment, under controlled conditions. Molecular analysis showed the tested isolates have close similarity to Daldinia eschscholtzii, Sarocladium oryzae, Rhizoctonia oryzae, Penicillium allahabadense, and Aspergillus foetidus. The combination of endophyte fungal isolates showed potential as plant growth promoters, however, further testing on several plant types is required before the combination is to be widely applied.
\end{abstract}

Keywords: Gibberellin, IAA, phosphate-solubilizing, and siderophore

\section{INTRODUCTION}

Microorganisms, including a group of plant growthpromoting bacteria and fungi, called plant growthpromoting rhizobacteria (PGPR) and plant growthpromoting fungi (PGPF) respectively, have an important role in plant growth (Pieterse et al. 2012; Zhang et al. 2019). Furthermore, PGPF positively impacts environmental ecology (Zhou et al. 2018), directly as well as indirectly, and stimulates plant growth by secreting growth-promoting hormones (El-Maraghy et al. 2020), thus, supporting plants to obtain the nutrients available in soil (Murali et al. 2012; Abdel-Motaal et al. 2020), and offering protection from pathogenic infections (Jogaiah et al. 2018; Abdel-Motaal et al. 2020).

An endophyte is microorganism of fungi or bacteria origin, with the ability to colonize plant tissues during the life cycle, without causing any adverse symptoms (Tan and Zou 2001; Gunatilaka 2006; Duhan et al. 2020). These microorganisms also promote nutrient absorption and protect host plants from both abiotic and biotic stresses
(Fadiji and Bababola 2020). Thus, endophytic fungi are fungi able to live in plant tissue without causing symptoms to the host plants (Hilarino et al. 2011; Afandhi et al. 2018).

These fungi play an important role in the ecosystem as well as plant growth (Zheng et al. 2017; Afandhi et al. 2018), produce bioactive molecules (Spellberg et al. 2008; Vasundhara et al. 2016; Manganyi et al. 2019; Techaoei et al. 2020), phytohormones (IAA, gibberellins, and cytokinins) (Lu et al. 2000; Barka et al. 2002) (Wulandari and Suryantini 2019), as well as siderophore (Neilands 1952; Ghosh et al. 2017), and also act as phosphate solvent (Malinowski and Belesky 1999; Hamayun et al. 2011).

IAA is a highly important phytohormone for the formation and elongation of plant roots, root hairs, as well as lateral root, in order to increase both nutrients and air absorption as well as plant development (Mishra et al. 2009; Ahmed and Hasnain 2010; Hussain et al. 2013; Hagaggi and Mohamed 2020). Meanwhile, auxin also plays an important role in root formation (Casimiro et al. 2001; Sapareng et al. 2017), and the IAA produced by endophytic 
fungi has the ability to increase plant growth and productivity (Yuan et al. 2010; Widowati et al. 2016).

According to Khan et al. (2013, 2017), Gibberellin plays a role in plant growth and helps to deal with abiotic stress. This phytohormone is produced by fungi, including Fusarium, Aspergillus, and Penicillium (Tudzynski 2005; Leitão and Enguita 2016).

In addition, Microbial phosphate solvent affects plant growth as well as development (Tallapragada and Gudimi 2011; Alori et al. 2017), and is able to improve phosphorus uptake in plants, thus, reducing the use of chemical fertilizers with a negative impact on the environment (Alori et al. 2017). Microorganisms produce siderophores under iron-deficient conditions (Schwyn and Neilands, 1987; Ahmed and Holmström 2014). These siderophores are classified into large groups of catechol, hydroxamate, and carboxylate, depending on the chemical nature of the coordination sites with iron (Ahmed and Holmström 2014). In addition, Calvente et al. (1999) and Halo et al. (2018) reported the siderophore produced by Rodhotorula glutinis is able to suppress blue rot disease on apple plants.

The application of PGPF isolates is able to induce plant growth, and the endophytic application on cucumber (Cucumis sativus L) plants showed increased biomass and plant growth. However, the inoculation of two or more microbial species produces increased growth and production, compared to a single application. The combination of Aspergillus terreus and Acremonium strictum inhibits root-knot disease in tomato plants (Elsharkawy and El-Khateeb 2019; Waqas et al. 2012; Navale et al. 1995; Saxena et al. 2015; Singh and Mathur 2010; Halo et al. 2018).

Therefore, the aims of this study were to select a combination of endophytic fungal isolates with the best ability to produce phytohormones, siderophores as well as phosphate-solubilizing metabolites, determine the effect of a combination of endophytic fungal isolates on cucumber germination and growth, and to identify the fungal isolates used, by pairs, followed by sequencing.

\section{MATERIALS AND METHODS}

\section{Preparation of endophytic fungi isolates and the combination of endophytic fungal isolates}

The six isolates of endophytic fungi were derived from South Sulawesi local rice and cultivated on PDA media at $28^{\circ} \mathrm{C}$, for 7 days.

\section{Combination design of endophytic fungi isolates}

The six endophytic fungal isolates were combined to obtain 15 combinations. These are F1-F5 (2 isolates combination), F6-F9 (3 isolates combination), F10 and F11 (4 isolates combination), F12 and F14 (5 isolates combination), as well as F15 (6 isolates combination) (Table 1).

\section{The IAA production analysis}

For this analysis, the 15 combinations of endophytic fungi were inoculated on Potato Dextrose Broth (PDB) media, L-tryptophan (0.1 g. $\left.\mathrm{L}^{-1}\right)$ was added, and the combinations were left to stand in the dark for five days, at $28^{\circ} \mathrm{C}$. Subsequently, the combination cultures were harvested and centrifuged at $6000 \mathrm{rpm}$ for 15 minutes, and $1 \mathrm{~mL}$ supernatant was obtained from each consortium and transferred into a test tube containing Salkowski reagent (Glickman and Dessaux 1995). This solution was then placed in the darkroom for 24 hours, at $28^{\circ} \mathrm{C}$, and absorbance was measured at a wavelength of 535 .

\section{The gibberellins production analysis}

The gibberellins production test was performed using the standard method, as described by Borrow et al. (1955). For this analysis, 15 combinations were inoculated on PDB medium for 7 days. Subsequently, the harvested cultures were centrifuged at $8000 \mathrm{rpm}$ for 10 minutes and $15 \mathrm{~mL}$ of supernatant was collected and transferred into a test tube. This was followed by adding $2 \mathrm{~mL}$ of zinc acetate and leaving the mixture to stand for 2 minutes, before adding 2 $\mathrm{mL}$ of potassium ferrocyanide solution. The mixture was then centrifuged at $800 \mathrm{rpm}$ for 10 minutes and $5 \mathrm{~mL}$ of supernatant was transferred into a test tube, $30 \%$ hydrochloric acid was added, and the mixture was incubated at $27^{\circ} \mathrm{C}$, for 75 minutes. Subsequently, absorbance was measured at a wavelength of $254 \mathrm{~nm}$, with a UV-VIS spectrophotometer.

\section{Phosphate solvent test}

The combination of endophytic fungi isolates was analyzed to determine the phosphate solubilizing ability quantitatively, using Pikovskaya, and $\mathrm{Ca}_{3}\left(\mathrm{PO}_{4}\right)_{2}$ as a source of phosphate. Pikovskaya media was prepared using $0.5 \mathrm{~g}$ of $\left(\mathrm{NH}_{4}\right) 2 \mathrm{SO}_{4}, 0.1 \mathrm{~g}$ of $\mathrm{MgSO}_{4} \cdot 7 \mathrm{H}_{2} \mathrm{O}, 0.02 \mathrm{~g}$ of $\mathrm{NaCl}, 0.02$ $\mathrm{g} \mathrm{KCl}, 0.003 \mathrm{~g}$ of $\mathrm{FeSO}_{4} \cdot 7 \mathrm{H}_{2} \mathrm{O}, 0.003 \mathrm{~g}$ of $\mathrm{MnSO}_{4} \cdot \mathrm{H}_{2} \mathrm{O}, 5 \mathrm{~g}$ of $\mathrm{Ca}_{3}\left(\mathrm{PO}_{4}\right)_{2}, 10.0 \mathrm{~g}$ of glucose, $0.5 \mathrm{~g}$ of yeast extract, $15.0 \mathrm{~g}$ of agar, and $1000 \mathrm{~mL}$ of distilled water (Elias et al. 2016).

Each combination was grown on liquid Pikovskaya media and incubated for 7 days. The cultures of each endophytic fungi isolate consortium were then harvested and filtered using Whatman paper no 42.

Table 1. The combination of six endophytic fungi isolates

\begin{tabular}{ll}
\hline Combination code & \multicolumn{1}{c}{$\begin{array}{c}\text { Combination of endophytic fungi } \\
\text { isolates }\end{array}$} \\
\hline F1 & $\mathrm{E} 1+\mathrm{E} 2$ \\
F2 & $\mathrm{E} 1+\mathrm{E} 3$ \\
F3 & $\mathrm{E} 1+\mathrm{E} 4$ \\
F4 & $\mathrm{E} 1+\mathrm{E} 5$ \\
F5 & $\mathrm{E} 1+\mathrm{E} 6$ \\
F6 & $\mathrm{E} 1+\mathrm{E} 2+\mathrm{E} 3$ \\
F7 & $\mathrm{E} 1+\mathrm{E} 2+\mathrm{E} 4$ \\
F8 & $\mathrm{E} 1+\mathrm{E} 2+\mathrm{E} 5$ \\
F9 & $\mathrm{E} 1+\mathrm{E} 2+\mathrm{E} 6$ \\
F10 & $\mathrm{E} 1+\mathrm{E} 2+\mathrm{E} 3+\mathrm{E} 4$ \\
F11 & $\mathrm{E} 1+\mathrm{E} 2+\mathrm{E} 3+\mathrm{E} 5$ \\
F12 & $\mathrm{E} 1+\mathrm{E} 2+\mathrm{E} 3+\mathrm{E} 6$ \\
F13 & $\mathrm{E} 1+\mathrm{E} 2+\mathrm{E} 3+\mathrm{E} 4+\mathrm{E} 5$ \\
F14 & $\mathrm{E} 1+\mathrm{E} 2+\mathrm{E} 3+\mathrm{E} 4+\mathrm{E} 6$ \\
F15 & $\mathrm{E} 1+\mathrm{E} 2+\mathrm{E} 3+\mathrm{E} 4+\mathrm{E} 5+\mathrm{E} 6$ \\
\hline
\end{tabular}


Subsequently, the filtrate was centrifuged at $1000 \mathrm{rpm}$ for 15 minutes, and $5 \mathrm{~mL}$ of supernatant was transferred into a test tube, with $0.5 \mathrm{~mL}$ of concentrated reagent $(12 \mathrm{~g}$ ammonium molybdate, $0.277 \mathrm{~g}$ potassium tinolartate) as well as dye concentrated reagent $(0.53 \mathrm{~g}$ ascorbic acid), shaken for a few minutes, and left to stand for 30 minutes. The absorbance of the solution was then measured with a spectrophotometer at a wavelength of $693 \mathrm{~nm}$.

\section{The siderophore production analysis}

This was carried out by growing the 15 combinations on PDB medium at $28^{\circ} \mathrm{C}$, for 7 days, then harvesting and filtering with a filter paper. The filtrate obtained was centrifuged at $10,000 \mathrm{rpm}$ for 20 minutes, and the supernatant was removed then adjusted to $\mathrm{pH} 2.0$ using HCL solution. Subsequently, $20 \mathrm{~mL}$ of this supernatant was collected, macerated with $20 \mathrm{~mL}$ of ethyl acetate, and subjected to extraction, twice. This was followed by adding $5 \mathrm{~mL}$ of Hathway reagent $(1 \mathrm{~mL} 0.1 \mathrm{M}$ ferric chloride and $1 \mathrm{~mL} 0.1 \mathrm{~N} \mathrm{HCl}$, added to $100 \mathrm{~mL}$ distilled water and $1 \mathrm{~mL}$ $0.1 \mathrm{M}$ potassium ferricyanide) to $5 \mathrm{~mL}$ of the test solution. The quantitative siderophore measurement was then conducted by measuring the absorbance of each endophytic fungal isolate's supernatant with a spectrophotometer at a wavelength of $560 \mathrm{~nm}$, using Sodium Salicylate as standard. Meanwhile, catechol was determined at $700 \mathrm{~nm}$ absorbance, using 2.3 DHBA as standard.

\section{The PGPF combination test on cucumber plants}

The spore suspension of each endophytic fungal isolate's combination was mixed with distilled water to obtain a spore concentration of 1 x $10^{6}$ CFU (Colony Forming Unit). Subsequently, the surface-sterilized cucumber seeds were planted on rockwool previously soaked with spore suspension and placed in a test tube filled with $50 \mathrm{~mL}$ of $\mathrm{AM}$ mix nutrient solution. Each treatment of the consortium of endophytic fungi isolates was repeated 3 times, thus, there were 45 treatment tubes and 3 as a control. Meanwhile, the nutrient solution was added after the volume had decreased. After 14 days of planting, the seeds had germinated and grown, and the plants were observed, based on the parameters of plant height, root length, and fresh weight.

\section{The molecular identification of endophytic fungal isolates}

This was conducted in the Indonesian Culture Collection (InaCC), Research Center for Biology, Indonesian Institute on Sciences (LIPI), Bogor, Indonesia, using molecular-based partial genetic analysis, at the internal transcribed spacer (ITS) locus of ribosomal DNA of fungi. Meanwhile, DNA isolation was carried out by growing the fungal isolate in (PDB) liquid medium and incubating it for 72 hours. The fungal mycelia biomass was then harvested for DNA extraction, performed using the nucleon reagent PHYTOpure (Amersham LIFE SCIENCE).

In addition, PCR amplification of ITS was carried out using ITS Primer 4: 5 -- TCC TCC GCT TAT TGA TAT GC-3 and ITS Primer 5: $5{ }^{`-G G A ~ A G T ~ A A A ~ A G T ~ C G T ~}$ AAC AAG G -3` (White et al. 1990; O`Donnell 1993).
Also, PCR product purification was performed using PEG precipitation method (Hiraishi et al. 1995), and followed by a sequencing cycle. The results of the sequencing cycle were re-purified using the Ethanol purification method, while the nitrogen base sequencereading was analyzed with an automated DNA sequencer (ABI PRISM 3130 Genetic Analyzer) (Applied Biosystems).

Subsequently, raw data from the sequencing was trimmed and assembled using the BioEdit program (http: //www.mbio.ncsu.edu/BioEdit/bioedit.html). The sequence data were then assembled in a subsequent BLAST, with genomic data registered in DDBJ/DNA Data Bank of Japan (http: //blast.ddbj.nig.ac.jp/) or NCBI/National Center for Biotechnology Information (http: //www.ncbi.nlm.nih.gov/BLAST/) in order to determine the taxa/species with the largest and closest homology/similarity in the molecular site.

\section{RESULTS AND DISCUSSION}

\section{IAA and gibberellin production}

According to the IAA and Gibberellin production capability test results on the 15 combinations of endophytic fungal isolates, the F13 combination containing 5 isolates, E1, E2, E3, E4, and E5, produced the best performance (Figure 1). Endophytic fungal are known to have an important role in stimulating the growth of host plants by producing secondary metabolites, including IAA, gibberellins, and siderophore. In this study, six endophytic fungi isolates derived from local rice plants in South Sulawesi, in the previous study, were combined and tested for plant growth-promoting ability. A study by Numponsak et al. (2018) reported only one of twenty-seven endophytic fungi isolates derived from the Coffea arabica plant in Northern Thailand, was able to produce IAA. In this study, the F13 consortium produced $3.89 \mathrm{mg} . \mathrm{L}^{-1}$ of IAA, and this is almost the same as the $37.034 \mu \mathrm{g} / \mathrm{ml}$ produced by Lasiodiplodia pseudotheobromae (Aramsirirujiwet and Kitpreechavanich 2016). This is also similar to the result of gibberellin-producing ability, reported for only 12 fungi ( MacMillan 2002; Kawaide 2006; Vandenbussche et al. 2007), including Fusarium, Aspergillus, and Penicillium (Leitão and Enguita 2016; Alori et al. 2017).

\section{Phosphate-solubilizing activity}

Based on the results, F1, containing two endophytic fungal isolates, E1 and E2 have the highest phosphatesolubilizing activity (8.64 mg. $\left.\mathrm{L}^{-1}\right)$, compared to other combinations (Figure 2). However, six other combinations, F2, F3, F4, F6, F10, and F15, were also able to dissolve phosphate in the range of 7.27-8.27 mg. $\mathrm{L}^{-1}$. Generally, the endophytic fungal combination's activity in dissolving phosphate is related to the type of endophytic fungal contained. The combination containing the endophytic fungal isolates E1, E2, E3, E4, and E5 had a higher dissolving ability, while the isolate E6 had a lower phosphate dissolving ability (0.68-5.47 mg. $\left.\mathrm{L}^{-1}\right)$. According to the results of molecular identification, E1 and E5 are Daldinia eschscholtzii, E2 is Sarocladium oryzae, E3 is 
Rhizoctonia oryzae, E4 is Penicillium allahabadense, and E6 is Aspergillus foetidus. This indicates Aspergillus foetidus has low phosphate dissolving ability, even in combination with other endophytic fungi. Reports by Srinivasan et al. (2012), Sharma et al. (2013), and Alori et al. (2017) stated Achrothcium, Alternaria, Arthrobotrys, Aspergillus, Cephalosporium, Cladosporium, Curvularia, Cunninghamella, Chaetomium, Fusarium, Glomus, Helminthosporium, Micromonospora, Mortierella, Myrothecium, Oidiodendron, Paecilomyces, Penicillium, Phoma, Pichia fermentans, Populospora, Pythium, Rhizoctonia, Rhizopus,
Saccharomyces, Schizosaccharomyces, Schwanniomyces, Sclerotium, Torula, Trichoderma, and Yarrowia, are examples of fungi with the ability to dissolve phosphates.

\section{Siderophore production}

The results showed Na-salicylate and catechol production in the 15 combinations. However, F11 and F1 combinations exhibited the highest concentration of $\mathrm{Na}$ salicylates (7.87 mg.L-1) and catechols (3.90 mg.L ${ }^{-1}$ ), respectively (Figure 3).

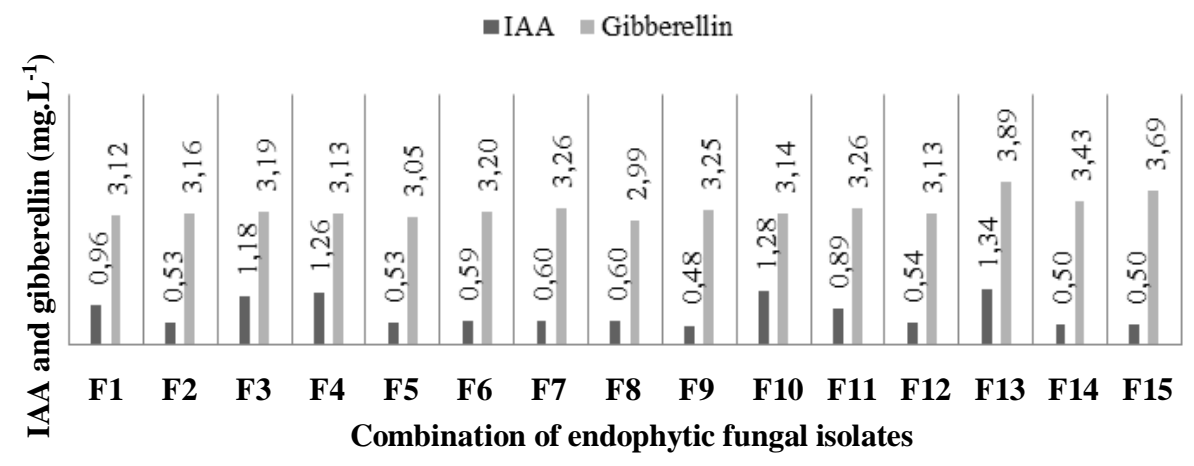

Figure 1. Production of phytohormones (IAA and gibberellin) by the combinations of endophytic fungal isolates

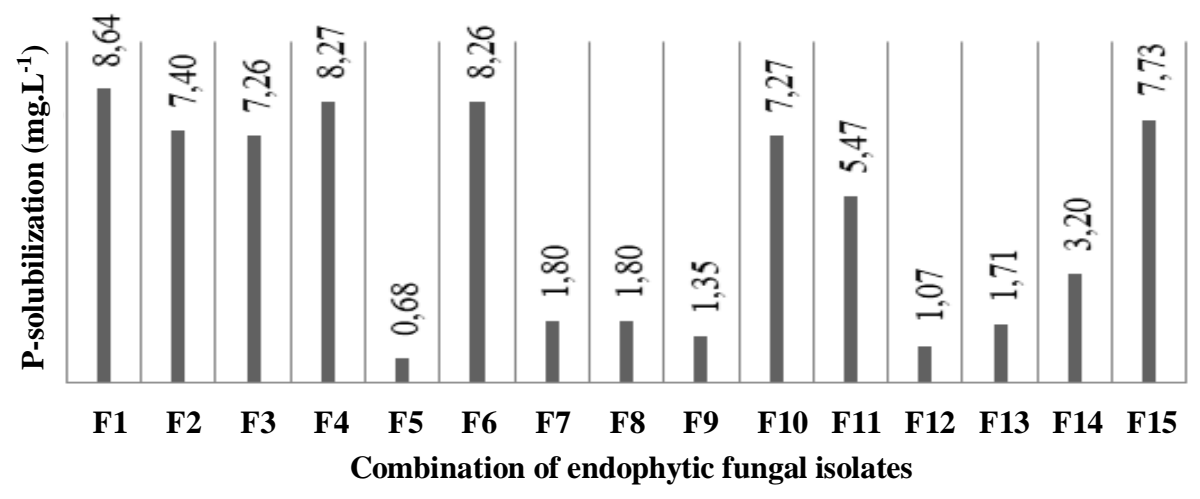

Figure 2. Phosphate solubilization activity of the consortium of endophytic fungal isolates

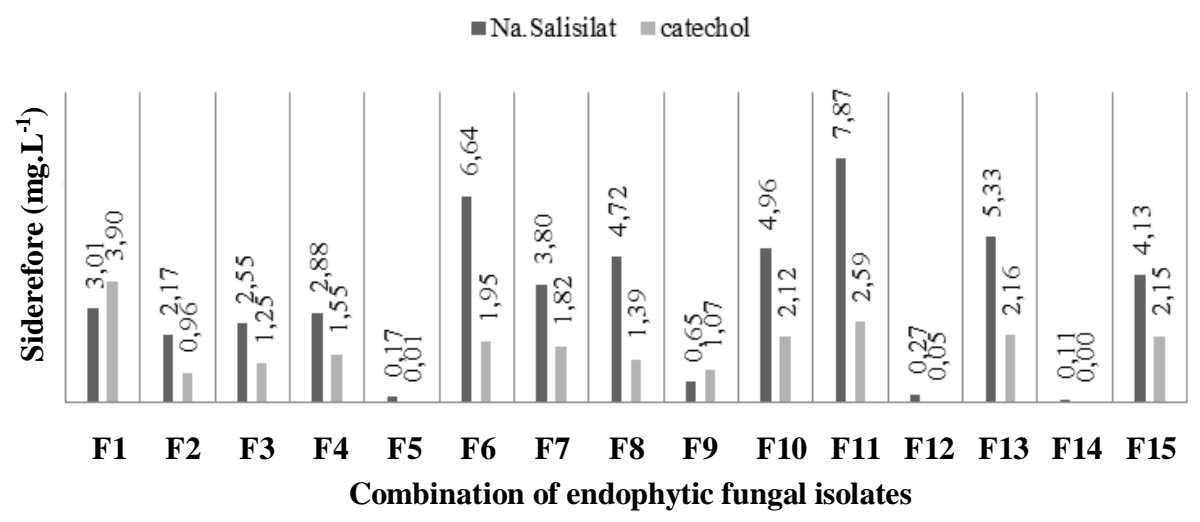

Figure 3. The production of Siderophore ( Na-salicylate and catechol) combination by endophytic fungal isolates 
The F11 consortium contained E1, E2, E3, and E5 isolates, while $\mathrm{F} 1$ contained $\mathrm{E} 1$ and $\mathrm{E} 2$. In terms of siderophores, F1 consortium shows the highest catechol activity, while F11 exhibits the highest salicylate concentration of $3.90 \mathrm{mg} . \mathrm{L}^{-1}$ and $7.87 \mathrm{mg} . \mathrm{L}^{-1}$, respectively. Kesaulya et al. (2018) reported Bacillus subtilis HPC21 strain was able to produce $4.21 \mathrm{mg} . \mathrm{L}^{-1}$ of siderophore (Verma et al. 2011; Ahmed and Holmström 2014). The effect of endophytic fungal isolates inoculation is able to cause significant increase in the parameters of plant height, root length, and fresh weight, in cucumber plants. In this study, the F6, F8, F9, and F12 combinations showed the best result for the plant height. Meanwhile, F4 combination, containing isolates E1 and E5, resulted in the highest root length of 38.67 .

\section{Application of endophytic fungal isolate combination in plants}

An endophytic fungi's ability to produce phytohormones, including IAA and gibberellin, is highly significant and necessary for increasing plant growth. According to Strobel et al. (2004) and Syamsia et al. (2015), indole acetic acid is an essential compound for growth, root, and shoot development, produced by microbes. Salazar-Cerezo et al. (2018) also described gibberellin's role, and the phytohormone has a vital function in plant growth processes, including seed germination, stem elongation, flowering, and fruit development. The activity of the fifteen combinations of endophytic fungal isolates in this study varied in the IAA and gibberellin-producing activity. However, isolate F13 was discovered to have the highest phytohormoneproducing ability.

After nitrogen, phosphate is the second main nutrient required for plant growth, however, about $95-99 \%$ of existing phosphate is insoluble, and therefore not utilizable by plants (Vassileva et al. 1998; Patil et al. 2011). A study by Alori et al. (2017) showed Phosphate Solubilizing Microorganisms (PSM) increase the bioavailability of soil insoluble phosphorus for plant use. The fifteen endophytic fungi combinations showed varied phosphate dissolving activity, with F1 exhibiting the highest activity.

Meanwhile, siderophore is an iron-chelating agent with a small molecular size, produced by microorganisms and plants in iron deficiency conditions (Schwyn and Neiland, 1987; Ahmed and Holmstrom 2014; Syamsia et al. 2020). The siderophore's primary function is to chelate iron and form complex compounds with $\mathrm{Cd}, \mathrm{Cu}, \mathrm{Zn}$ and other heavy metals (Jonstone and Nolan 2015; Syamsia et al. 2020). In this study, the ability of endophytic fungi combinations to produce two types of siderophores varied, with F1 and F11 producing the highest catechol and Na-salicylate levels, respectively.

Figure 4 shows the cucumber seeds began to germinate on the third day after planting, as indicated by the presence of plumules and roots, and all the seeds were fully germinated by the seventh day. The plants were maintained up to 14 days by controlling the volume of nutrients in the tube daily (Figure 5). According to the results, consortium F8 produced the highest plant fresh weight of $26.83 \mathrm{~g}$. A study by Syed et al. (2020) showed the PGPR consortium application (Aspergillus niger; A. flavus; Fusarium oxysporum) resulted in higher germination and root induction rates, compared to the control, while a report by Halo et al. (2018) stated the isolates of Aspergillus terreus (65P and 9F) were able to increase germination by 10 to $20 \%$, in cucumber plants, under controlled condition. Meanwhile, Hamayun et al. (2011) used the gibberellinproducing Neosartorya fungus to stimulate growth in Brassica rapa L ssp. pekinensis Kursiv.

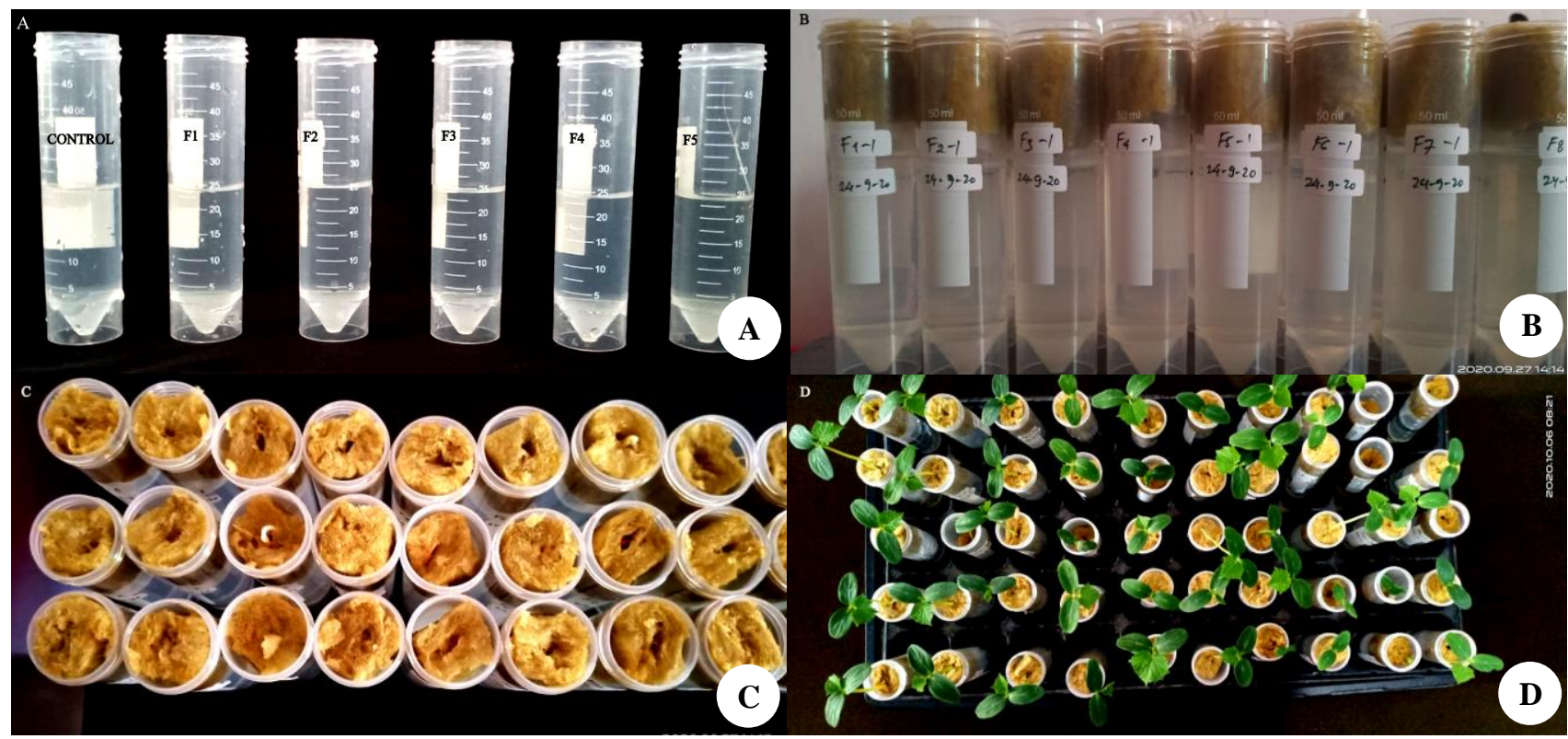

Figure 4. Cucumber seed germination and growth in the inoculation treatment, using the endophytic fungal isolate combinations 


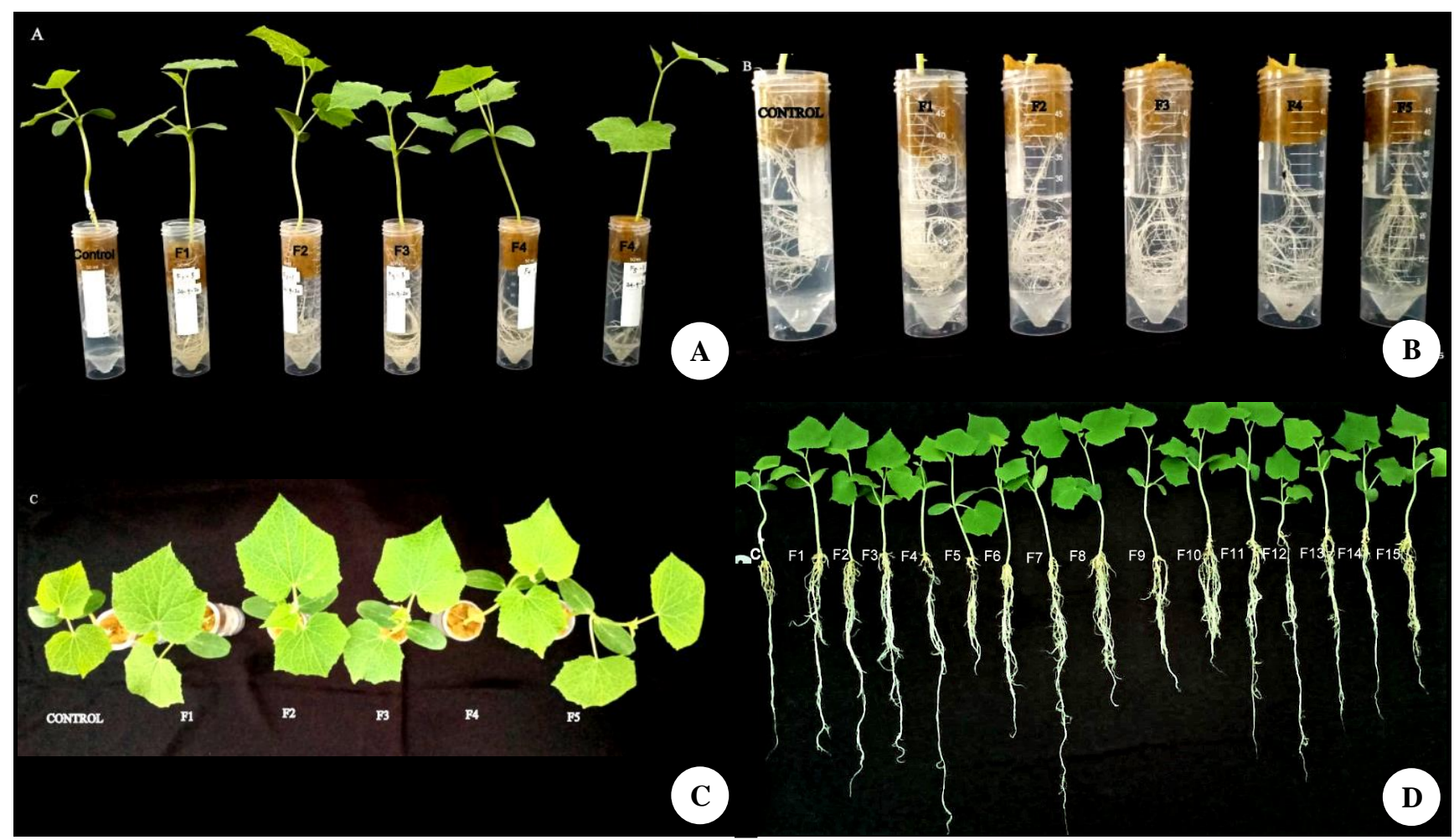

Figure 5. Plant growth of cucumber plant treated with a combination of endophytic fungal isolates, at age 14 days (A), roots (B), leaves (C), and plant (D)

Table 2 shows the inoculation of endophytic fungal isolate combinations was able to significantly increase the plant height, root length, and fresh weight of cucumber. The combinations F6, F8, F9, and F12 showed the best result for plant height, while the F4 and F8 resulted in the best root length, and plant fresh weight, respectively. Based on data analysis, all the results were significantly different.

Table 2. The effect of endophytic fungi combination inoculation on plant height, root length, and fresh weight of cucumber at 14 days after planting.

\begin{tabular}{cccc}
\hline Treatments & $\begin{array}{c}\text { Shoot } \\
\text { length }(\mathbf{c m})\end{array}$ & $\begin{array}{c}\text { Root length } \\
(\mathbf{c m})\end{array}$ & $\begin{array}{c}\text { Fresh weight } \\
(\mathbf{g})\end{array}$ \\
\hline Control & $11.00^{\mathrm{d}}$ & $21.10^{\mathrm{h}}$ & $12.10^{\mathrm{g}}$ \\
F1 & $11.00^{\mathrm{d}}$ & $26.63^{\mathrm{g}}$ & $12.25^{\mathrm{g}}$ \\
F2 & $11.17^{\mathrm{cd}}$ & $30.67^{\mathrm{d}}$ & $23.13^{\mathrm{b}}$ \\
F3 & $14.00^{\mathrm{b}}$ & $28.50^{\mathrm{ef}}$ & $21.57^{\mathrm{c}}$ \\
F4 & $10.17^{\mathrm{e}}$ & $38.67^{\mathrm{a}}$ & $15.96^{\mathrm{f}}$ \\
F5 & $11.83^{\mathrm{cd}}$ & $15.33^{\mathrm{l}}$ & $17.97^{\mathrm{e}}$ \\
F6 & $15.17^{\mathrm{a}}$ & $22.67^{\mathrm{h}}$ & $21.97^{\mathrm{bc}}$ \\
F7 & $12.93^{\mathrm{c}}$ & $36.33^{\mathrm{b}}$ & $21.97^{\mathrm{bc}}$ \\
F8 & $15.15^{\mathrm{a}}$ & $22.67^{\mathrm{h}}$ & $26.83^{\mathrm{a}}$ \\
F9 & $15.12^{\mathrm{a}}$ & $17.67^{\mathrm{k}}$ & $22.40^{\mathrm{bc}}$ \\
F10 & $15.12^{\mathrm{a}}$ & $18.33^{\mathrm{j}}$ & $20.36^{\mathrm{d}}$ \\
F11 & $14.28^{\mathrm{b}}$ & $29.33^{\mathrm{e}}$ & $18.23^{\mathrm{e}}$ \\
F12 & $15.23^{\mathrm{a}}$ & $34.67^{\mathrm{c}}$ & $21.53^{\mathrm{c}}$ \\
F13 & $7.00^{\mathrm{f}}$ & $27.33^{\mathrm{fg}}$ & $14.86^{\mathrm{f}}$ \\
F14 & $12.17^{\mathrm{c}}$ & $27.67^{\mathrm{f}}$ & $19.40^{\mathrm{d}}$ \\
F15 & $10.67^{\mathrm{e}}$ & $20.33^{\mathrm{i}}$ & $19.33^{\mathrm{d}}$ \\
\hline
\end{tabular}

\section{Molecular identification}

The nearest taxon of BLAST homology results in DDBJ/NCBI ([http: //www.ncbi.nlm.nih.gov/) showed the endophytic fungal isolates E1, E5, and E6 obtained 100\% homology and $100 \%$ query coverage with Daldinia eschscholtzii isolate UZ_108_16 and Daldinia eschscholtzii culture-collection JMRC: SF: 11930 for E1, Talaromyces allahabadensis (anamorph: Penicillium allahabadense) isolate HNMF013 and Daldinia eschscholtzii isolate UZ_108_16 for E5, as well as Aspergillus foetidus CBS 121.28 Aspergillus foetidus isolate BM13, foe E6. Meanwhile, isolate E2 showed $99.83 \%$ homology and $99 \%$ query coverage with Sarocladium oryzae culture collection CBS 399.73, as well as $98.80 \%$ homology and $99 \%$ query coverage with Sarocladium oryzae isolate Saro11. In addition, isolate E3 showed $90.01 \%$ homology and $100 \%$ query coverage with Rhizoctonia oryzae CBS 273.38 strain, as well as $98.20 \%$ homology and 99\% query coverage with Rhizoctonia oryzae CBS 475.82 strain, while isolate E4 showed 100\% homology and $56 \%$ query coverage with Talaromyces allahabadensis (anamorph: Penicillium allahabadense isolate Yu3-6 and Talaromyces allahabadensis (anamorph: Penicillium allahabadense) isolate HNMF013 (Table 3).

Based on the identification, several endophytic fungal isolates, including Daldinia eschscholtzii, have also been isolated from the genus Xestospongia sponge and are able to produce secondary metabolites (Sibero et al. 2020). According to Sunariasih et al. (2014), the fungus Sarocladium oryzae isolated from rice seeds has an inhibitory power against Pyricularia oryzae, the cause of blast disease in rice plants. 
Table 3. Molecular identification of endophytic fungi isolates

\begin{tabular}{|c|c|c|c|c|c|c|c|c|c|}
\hline $\begin{array}{l}\text { Fungal } \\
\text { isolate }\end{array}$ & $\begin{array}{l}\text { GenBank } \\
\text { acc. no. }\end{array}$ & $\begin{array}{l}\text { Homology } \\
\quad(\%)\end{array}$ & $\begin{array}{l}\text { Max. } \\
\text { score }\end{array}$ & $\begin{array}{l}\text { Total } \\
\text { score }\end{array}$ & $\begin{array}{c}\text { Query } \\
\text { coverage } \\
(\%)\end{array}$ & $\begin{array}{c}\text { E- } \\
\text { value }\end{array}$ & $\begin{array}{c}\text { Max. } \\
\text { identities } \\
(\%)\end{array}$ & $\begin{array}{c}\text { Gabs } \\
(\%)\end{array}$ & Endophytic fungi \\
\hline \multirow[t]{2}{*}{$\overline{\mathrm{E} 1}$} & KY79260 & 100 & 1051 & 1051 & 100 & 0.0 & 100 & 0 & Daldinia eschscholtzii isolate UZ_108_16 \\
\hline & KU304335 & 100 & 1051 & 1051 & 100 & 0.0 & 100 & 0 & $\begin{array}{l}\text { Daldinia eschscholtzii culture-collection JMRC: } \\
\text { SF: } 11930\end{array}$ \\
\hline \multirow[t]{2}{*}{ E2 } & HG965027 & 99.83 & 1066 & 1066 & 99 & 0.0 & 99 & 0 & $\begin{array}{l}\text { Sarocladium oryzae culture collection CBS } \\
399.73\end{array}$ \\
\hline & KT291722 & 98.80 & 1033 & 1033 & 99 & 0.0 & 99 & 0 & Sarocladium oryzae isolate Saro11 \\
\hline \multirow[t]{2}{*}{ E3 } & MH855962 & 99.01 & 1092 & 1092 & 100 & 0.0 & 99 & 0 & Rhizoctonia oryzae strain CBS 273.38 \\
\hline & MH861520 & 98.20 & 1072 & 1072 & 100 & 0.0 & 98 & 0 & Rhizoctonia oryzae strain CBS 475.82 \\
\hline \multirow[t]{2}{*}{ E4 } & MG827185 & 100 & 992 & 992 & 56 & 0.0 & 100 & 0 & $\begin{array}{l}\text { Talaromyces allahabadensis (anamorph: } \\
\text { Penicillium allahabadense isolate Yu3-6 }\end{array}$ \\
\hline & HNMF013 & 100 & 992 & 992 & 56 & 0.0 & 100 & 0 & $\begin{array}{l}\text { Talaromyces allahabadensis (anamorph: } \\
\text { Penicillium allahabadense) isolate HNMF013 }\end{array}$ \\
\hline \multirow[t]{2}{*}{ E5 } & KY792620 & 10 & & 10 & 100 & 0.0 & 100 & 0 & Daldinia eschscholtzii isolate UZ_108_16 \\
\hline & KU304335 & 100 & 1051 & 1051 & 100 & 0.0 & 100 & 0 & $\begin{array}{l}\text { Daldinia eschscholtzii culture-collection JMRC: } \\
\text { SF: } 11930\end{array}$ \\
\hline \multirow[t]{2}{*}{ E6 } & NR1 & 10 & & & 100 & 0.0 & 100 & 0 & Aspergillus foetidus CBS 121.28 \\
\hline & MK910068 & 100 & 1101 & 1101 & 100 & 0.0 & 100 & 0 & Aspergillus foetidus isolate BM13 \\
\hline
\end{tabular}

Meanwhile, Rhizoctonia oryzae has the ability to cause midrib disease in plants, and Aspergillus flavus is a producer of aflatoxin, the most dangerous mycotoxin. However, several studies indicate Aspergillus flavus is able to inhibit the growth of Septobasidium sp. and also has the potential to act as a biological agent (Suswanto et al. 2018), in addition to absorbing chromium, and is, therefore, suitable for processing waste containing hexavalent chromium (Vinay and Dwivedi 2019) and increasing tomato's resistance to blight (Abdel Motaal et al. 2020). Reports by Berg and Hallmann (2006), as well as Sucipto et al. (2015) show endophytic fungi's mechanism of direct inhibition against pathogens is through antibiosis, competition, as well as lysis, while the indirect mechanism involves inducing plant resistance and increasing plant growth. However, the endophytic fungi tested in this study need to be tested for tobacco plants' pathogenicity. Furthermore, a hemolysis test was conducted to determine the effect on human health before being widely applied to plants as a growth enhancer and biocontrol.

In this study, a combination of endophytic fungi isolates showed IAA, gibberellin and siderophore production, as well as varying phosphate-dissolving activities. In addition, the fungal isolate combination was able to increase the plant height, root length as well as plant fresh weight, and the best combination of endophytic fungi isolates was F1, F4, F8, and F13. However, further studies on several plant types are required before the combination is to be widely applied.

\section{ACKNOWLEDGEMENTS}

The authors are grateful to the Ministry of Research and Technology/National Research and Innovation Agency, Indonesia for the provision of full financial aid towards this study, under the PDUPT scheme, 2020.

\section{REFERENCES}

Abdel-Motaal F, Kamel N, El-Zayat S, Abou-Ellail M. 2020. Early blight suppression and plant growth promotion potential of the endophyte Aspergillus flavus in tomato plant. Ann Agric Sci 65 (2): 117-123. DOI: 10.1016/j.aoas.2020.07.001.

Afandhi A, Choliq FA, WS HA, Tarno H. 2018. Distribution of the endophytic fungi in apple leaves. Agrivita J Agric Sci 40 (1): 91-100. DOI: 10.17503/agrivita.v40i1.1563.

Ahmed E, Holmström SJ. 2014. Siderophores in environmental research: roles and applications. Microb Biotechnol 7 (3): 196-208.. DOI: 10.1111/1751-7915.12117.

Ahmed A, Hasnain S. 2010. Auxin-producing Bacillus sp.: Auxin quantification and effect on the growth of Solanum tuberosum. Pure Appl Chem 82: 313-319. DOI: 10.1351/PAC-CON-09-02-06.

Alori ET, Glick BR, Babalola OO. 2017. Microbial phosphorus solubilization and its potential for use in sustainable agriculture. Front Microbiol 8: 1-8. DOI: 10.3389/fmicb.2017.00971.

Aramsirirujiwet Y, Gumlangmak C, Kitpreechavanich V. 2016. Studies on antagonistic effect against plant pathogenic fungi from endophytic fungi Isolated from Houttuynia cordata Thunb. and Screening for Siderophore and Indole-3-Acetic Acid Production. Asia-Pacific J Sci Technol 21 (1): 55-66. DOI: 10.14456/ kkurj.2016.5.

Barka AE, Gognies S, Nowak J, Audran JC, Belarbi A. 2002. Inhibitory effect of endophyte bacteria on Botrytis cinerea and its influence to promote the grapevine growth. Biol Control 24 (2): 135-142. DOI: 10.1016/S1049-9644(02)00034-8.

Berg G, Hallmann J. 2006. Control of Plant Pathogenic Fungi with Bacterial Endophytes. In: Schulz BJE, Boyle CJC, Sieber TN (eds) Microbial Root Endophytes. Soil Biology, vol 9. Springer, Berlin, Heidelberg. DOI.10.1007/3-540-33526-9_4.

Borrow A, Brian PW, Chester VE, Curtis PJ, Hemming HG, Henehan C, Jeffreys EG, Lloyd PB, Nixon IS, Norris GL, Radley M. 1955. Gibberellic acid, a metabolic product of the fungus Gibberella fujikuroi: some observations on its production and isolation. J Sci Food Agric 6 (6): 340-348.

Calvente V, Benuzzi D, de Tosetti MS. 1999. Antagonistic action of siderophores from Rhodotorula glutinis upon the postharvest pathogen Penicillium expansum. Intl Biodeter Biodegrad 43: 167-172. DOI: 10.1016/ S0964-8305(99)00046-3.

Casimiro I, Marchant A, Bhalerao RP, Beeckman T, Dhooge S, Swarup R, Graham N, Inzé D, Sandberg G, Casero PJ, Bennett M. 2001. Auxin transport promotes Arabidopsis lateral root initiation. Plant Cell 13: 843-852. DOI: $10.1105 /$ tpc.13.4.843.

Duhan P, Bansal P, Rani S. 2020. Isolation, identification and characterization of endophytic bacteria from medicinal Plant 
Tinospora cordifolia. S Afr J Bot 132: 43-49. DOI: 10.1016/j.sajb. 2020. 01.047 .

El-Maraghy SS, Tohamy TA, Hussein KA. 2020. Role of plant-growth promoting fungi (PGPF) in defensive genes expression of Triticum aestivum against wilt disease. Rhizosphere 15: 100223. DOI 10.1016/j.rhisph.2020.100223.

Elias F, Woyessa D, Muleta D. 2016. Phosphate solubilization potential of rhizosphere fungi isolated from plants in Jimma zone, southwest Ethiopia. Intl J Microbiol 1. DOI: 10.1155/2016/5472601.

Elsharkawy MM, El-Khateeb NM. 2019. Antifungal activity and resistance induction against Sclerotium cepivorum by plant growthpromoting fungi in onion plants. Egypt J Biol Pest Control 29 (1). DOI: $10.1186 / \mathrm{s} 41938-019-0178-9$.

Fadiji AE, Babalola OO. 2020. Exploring the potentialities of beneficial endophytes for improved plant growth. Saudi J Biol Sci 27 (12) 3622-3633. DOI: $10.1016 /$ j.sjbs.2020.08.002.

Ghosh SK, Banerjee S, Sengupta C. 2017. Siderophore production by antagonistic fungi (Coleoptera: Chrysomelidae: Bruchinae) (C) 527 bioassay, characterization and estimation of siderophores from some important antagonistic fungi. J Biopest 10 (2): 105-112. http: //www.jbiopest.com/users/LW8/efiles/vol_10_2_105-112.

Gilickmann E, Dessaux YA. 1995. Critical examination of the specificity of the Salkowski reagent for indolic compounds produced by phytopathogenic bacteria. Appl Environ Microb 61: 793-796. DOI 10.1128/AEM.61.2.793-796.1995.

Gunatilaka AA. 2006. Natural products from plant-associated microorganisms: distribution, structural diversity, bioactivity, and implications of their occurrence. J Nat Prod 69 (3): 509-26. DOI: $10.1021 / \mathrm{np} 058128 \mathrm{n}$

Hagaggi NS, Mohamed AA. 2020. Enhancement of Zea mays (L.) growth performance using indole acetic acid-producing endophyte Mixta theicola isolated from Solenostemma argel (Hayne). S Afr J Bot: 1-8. DOI: 10.1016/j.sajb.2020.02.034

Halo BA, Al-Yahyai RA, Al-Sadi AM. 2018. Aspergillus terreus inhibits growth and induces morphological abnormalities in Pythium aphanidermatum and suppresses Pythium-induced damping-off of cucumber. Front Microbiol 9: 95. DOI: 10.3389/fmicb.2018.00095.

Hamayun M, Khan SA, Khan AL, Ahmad N, Nawaz Y, Sher H, Lee IJ. 2011. Gibberellin producing Neosartorya sp. cc8 reprograms Chinese cabbage to higher growth. Sci Hortic 129 (3): 347-52. DOI 10.1016/j.scienta.2011.03.046

Hilarino MP, Oki Y, Rodrigues L, Santos JC, Corrêa Junior A, Fernandes GW, Rosa CA. 2011. Distribution of the endophytic fungi community in leaves of Bauhinia brevipes (Fabaceae). Acta Bot Brasilica 25 (4): 815-821.DOI: $10.1590 / \mathrm{S} 0102-33062011000400008$

Hiraishi A, Kamagata Y, Nakamura K. 1995. Polymerase chain reaction amplification and restriction fragment length polymorphism analysis of 16S rRNA genes from methanogens. J Ferment Bioeng 79: 523529. DOI: https: //doi.org/10.1016/0922-338X(95)94742-A.

Hussain MI, Asghar HN, Arshad M, Shahbaz M. 2013. Screening of multi-traits rhizobacteria to improve maize growth under axenic conditions. J Anim Plant Sci 23: 514-520.

Jogaiah S, Abdelrahman M, Tran LS, Ito SI. 2018. Different mechanisms of Trichoderma virens-mediated resistance in tomato against Fusarium wilt involve the jasmonic and salicylic acid pathways. Mol Plant Pathol 19: 870-882. DOI: 10.1111/mpp.12571.

Johnstone TC, Nolan EM. 2015. Beyond iron: non-classical biological functions of bacterial siderophores. Dalton Transactions 44 (14): 6320-6339.

Kawaide H. 2006. Biochemical and molecular analysis of gibberellin biosynthesis in fungi. Biosci Biotechnol Biochem 70: 583-590. DOI: 10.1271/bbb.70.583

Kesaulya H, Hasinu JV, Tuhumury GN. 2018. Potential of Bacillus spp. produces siderophores in suppressing the wilt disease of banana plants. IOP Conf Ser: Earth Environ Sci 102 (1). DOI: 10.1088/1755 1315/102/1/012016.

Khan AL, Hussain J, Al-Harrasi A, Al-Rawahi A, Lee IJ. 2013 Endophytic fungi: a source of gibberellins and crop resistance to abiotic stress. Crit Rev Biotech 35 (1): 1-13. DOI: 10.3109/ 07388551. 2013.800018.

Khan AL, Gilani SA, Waqas M, Al-Hosni K, Al-Khiziri S, Kim YH, Ali L, Kang SM, Asaf S, Shahzad R, Hussain J, Lee IJ, Al-Harrasi A 2017. Endophytes from medicinal plants and their potential for producing indole acetic acid, improving seed germination and mitigating oxidative stress. J Zhejiang Univ Sci B 18 (2): 125-137. DOI: $10.1631 /$ jzus.B1500271.
Leitão AL, Enguita FJ. 2016. Gibberellins in penicillium strains: challenges for endophyte-plant host interactions under salinity stress. Microbiol Res 183: 8-18. DOI: 10.1016/j.micres.2015.11.004.

Lu H, Zou WX, Meng JC, Hu J, Tan RX. 2000. New bioactive metabolites produced by Colletotrichum sp., an endophytic fungus in Artemisia аппиа. Plant Sci 151 (1): 67-73. DOI: 10.1016/S01689452(99)00199-5.

MacMillan J. 2002. Occurrence of gibberellins in vascular plants, fungi and bacteria. J Plant Growth Reg 20 (21): 242-243. DOI: 10.1007/s00344-003-0004-0.

Manganyi MC, Regnier T, Tchatchouang CD, Bezuidenhout CC, Ateba CN. 2019. Antibacterial activity of endophytic fungi isolated from Sceletium tortuosum L. (Kougoed). Ann Microbiol 69 (6): 659-663. DOI: $10.1007 / \mathrm{s} 13213-019-1444-5$

Malinowski DP, Belesky DP. 1999. Neotyphodium coenophialumendophyte infection affects the ability of tall fescue to use sparingly available phosphorus. J Plant Nutr 22: 835-853. DOI: 10.1080/ 01904169909365675

Mishra BS, Singh M, Aggrawal P, Laxmi A. 2009. Glucose and auxin signaling interaction in controlling Arabidopsis thaliana seedlings root growth and development. PLoS One 4: e4502. DOI: 10.1371/journal.pone.0004502.

Murali M, Sudisha J, Amruthesh KN, Ito SI, Shetty HS.2013. Rhizosphere fungus Penicillium chrysogenum promotes growth and induces defense-related genes and downy mildew disease resistance in pearl millet. Plant Biol (Stuttg) 15 (1): 111-8. DOI: 10.1111/j.14388677.2012.00617.x

Navale AM, Shinde DB, Vaidya BR, Jadhav SB. 1995. Effects of Azotobacter and Azospirillum inoculation under graded levels of nitrogen on growth and yield of sugarcane (Saccharum officinarum). Indian J Agron 40: 665-669.

Neilands JB. 1952. A Crystalline Organo- iron pigment from a rust fungus (Ustilago sphaerogena). J Am Chem Soc 74: 4846.

Numponsak T, Kumla J, Suwannarach N, Matsui K, Lumyong S. 2018. Biosynthetic pathway and optimal conditions for the production of indole-3-acetic acid by an endophytic fungus, Colletotrichum fructicola CMU-A109. PLoS One 13 (10): e0205070. DOI: 10.1371/journal.pone.0205070.

O`Donnell K. 1993. Fusarium and its near relatives. In: Reynolds DR, Taylor JW (eds.). 1995. The Fungal Holomorph: Mitotic, Meiotic, and Pleomorphic specification in fungal systematics. CAB International, Wallingford, UK.

Patil CS, Sanjotha P, Mahantesh P. 2011. Isolation and screening of efficiency of phosphate solubilizing microbes. Intl J Microbiol Res 3 (1): 56-58. DOI: $10.9735 / 0975-5276.3 .1 .56-58$.

Pieterse CM, Van der Does D, Zamioudis C, Leon-Reyes A, Van Wees SC. 2012. Hormonal modulation of plant immunity. Annu Rev Cell Dev Biol 28: 489-521. DOI: 10.1146/annurev-cellbio-092910154055

Salazar-Cerezo S, Martínez-Montiel N, García-Sánchez J, Pérez-y-Terrón R, Martínez-Contreras RD. 2018. Gibberellin biosynthesis and metabolism: A convergent route for plants, fungi and bacteria. Microbiol Res 208: 85-98.

Sapareng S, Ala A, Kuswinanti T, Rasyid B. 2017. Capability of Rot Fungus Isolates from Oil Palm Empty Bunches in the Production of Indole Acetic Acid (IAA). Intl J Curr Microbiol Appl Sci 6 (11): 2174-80. DOI: https: //doi.org/10.20546/ ijcmas.2017.611.256.

Saxena, Jyoti, Amita Saini, Indu Ravi, Shalini Chandra, and Veena Garg. 2015. Consortium of phosphate-solubilizing bacteria and fungi for promotion of growth and yield of chickpea (Cicer arietinum). Journal $\begin{array}{lllll}\text { of } & \text { Crop Improvement } 29 & \text { (3): 353-69. DOI: }\end{array}$ 10.1080/15427528.2015.1027979.

Saxena J, Saini A, Ravi I, Chandra S, Garg V. 2015. Consortium of phosphate-solubilizing bacteria and fungi for promotion of growth and yield of chickpea (Cicer arietinum). J Crop Improv 29 (3): 35369. DOI: $10.1080 / 15427528.2015 .1027979$.

Schwyn B, Neilands JB. 1987. Universal chemical assay for the detection and determination of siderophores. Anal Biochem 160 (1): 47-56.

Sharma SB, Sayyed RZ, Trivedi MH, Gobi TA. 2013. Phosphate solubilizing microbes: sustainable approach for managing phosphorus deficiency in agricultural soils. Springerplus 2: 587-600. DOI: 10.1186/2193- 1801-2-587

Sibero MT, Zhou T, Igarashi Y, Radjasa OK, Sabdono A, Trianto A, Bachtiarini TU, Bahry MS. 2020. Chromanone-type compounds from marine sponge-derived Daldinia eschscholtzii KJMT FP 4.1. J Appl Pharm Sci 10 (1): 001-007. DOI: 10.7324/JAPS.2020.101001. 
Singh S, Mathur N. 2010. Biological control of root-knot nematode, Meloidogyne incognita infecting tomato. Biocontrol Sci Technol 20: 865-874. DOI: 10.1080/09583157.2010.487935.

Spellberg B, Guidos R, Gilbert D, Bradley J, Boucher HW, Scheld WM, Bartlett JG, Edwards J Jr. 2008. Infectious Diseases Society of America. The epidemic of antibiotic-resistant infections: a call to action for the medical community from the Infectious Diseases Society of America. Clin Infect Dis 46 (2): 155-64. DOI: 10.1086/524891. PMID: 18171244

Srinivasan R, Yandigeri MS, Kashyap S, Alagawadi AR. 2012. Effect of salt on survival and P-solubilization potential of phosphate solubilizing microorganisms from salt-affected soils. Saudi J Biol Sci 19: 427-434. DOI: 10.1016/j.sjbs.2012.05.004.

Strobel G, Daisy B, Castillo U, Harper J. 2004. Natural products from endophytic microorganisms. J Natural Prod 67 (2): 257-268.

Sucipto I, Munif A, Suryadi Y, Tondok ET. 2015. Eksplorasi cendawan endofit asal padi sawah sebagai agens pengendali penyakit blas pada padi sawah. J Fitopatol Indonesia 11 (6): 211-218. DOI: 10.14692/jfi.11.6.211. [Indonesian]

Sunariasih NP, Suada IK, Suniti NW. 2014. Identification of endophytic fungi from rice grain and its inhibiting ability by in vitro against Pyricularia oryzae Cav. Jurnal Agroekoteknologi Tropika 3 (2): 5160. [Indonesian]

Suswanto I, Simamora C, Anggorowati D. 2018. Effective endhophyte fungi as biological control agent in pepper (Piper nigrum L). Jurnal Agroqua: Media Informasi Agronomi dan Budidaya Perairan 16 (2): 143-151. DOI : 10.32663/ja.v16i2.482. [Indonesian]

Syamsia, Kuswinanti T, Syam'un E, Masniawati A. 2015. The potency of endophytic fungal isolates collected from local aromatic rice as Indole Acetic Acid (IAA) producer. Procedia Food Sci 3: 96-103. DOI: 10.1016/j.profoo.2015.01.009.

Syamsia, Idhan A, Patappari A, Noerfitryani. 2020. The potential of local rice endophytic fungi of South Sulawesi as a siderophore producer. Jurnal Galung Tropika 9 (2): 187-194. DOI: 10.31850/jgt.v9i2.659. [Indonesian]

Syed S, Tollamadugu NP, Lian B. 2020. Aspergillus and Fusarium control in the early stages of Arachis hypogaea (groundnut crop) by plant growth-promoting rhizobacteria (PGPR) Consortium. Microbiol Res 240 (1): 126562. DOI: 10.1016/j.micres.2020.126562.

Tallapragada P, Gudimi M. 2011. Phosphate solubility and biocontrol activity of Trichoderma harzianum. Turk J Biol 35: 593-600. DOI: 10.3906/biy-0911-4.

Tan RX, Zou WX. 2001. Endophytes: a rich source of functional metabolites. Nat Prod Rep 18 (4): 448-459.

Techaoei S, Jirayuthcharoenkul C, Jarmkom K, Dumrongphuttidecha T, Khobjai W. 2020. Chemical Evaluation and Antibacterial Activity of Novel Bioactive Compounds from Endophytic Fungi in Nelumbo Nucifera. Saudi J Biol Sci 27 (11): 2883-2889. DOI: 10.1016/j.sjbs.2020.08.037.

Tudzynski B. 2005. Gibberellin biosynthesis in fungi: genes, enzymes, evolution, and impact on biotechnology. Appl Microbiol Biotechnol 66: 597-611. DOI: 10.1007/s00253-004-1805-1.
Vandenbussche F, Fierro AC, Wiedemann G, Reski R, Van Der Straeten D. 2007. Evolutionary conservation of plant gibberellin signaling pathway components. BMC Plant Biol 7: 65. DOI: 10.1186/14712229-7-65

Vasssilevea M, Vassilev N, Azcon R. 1998. Rock phosphate solubilization by Aspergillus niger on olive cake-based medium and its further application in soil-plant system. World J Microbiol Biotech 14: 281284. DOI: 10.1023/A: 1008858802855.

Vasundhara M, Kumar A, Reddy MS. 2016. Molecular approaches to screen bioactive compounds from endophytic fungi. Front Microbiol 7: 1-12. DOI: 10.3389/fmicb.2016.01774.

Verma VC, Singh SK, Prakash S. 2011. Bio-control and plant growth promotion potential of siderophore producing endophytic Streptomyces from Azadirachta indica A. Juss. J Basic Microbiol 51: 550-556. DOI: 10.1002/ jobm.201000155.

Vinay K, Dwivedi SK. 2019. Hexavalent chromium reduction ability and bioremediation potential of Aspergillus flavus CR500 isolated from electroplating wastewater, Chemosphere 237. DOI: 10.1016 /j.chemosphere. 2019.124567.

Waqas M, Khan AL, Kamran M, Hamayun M, Kang SM, Kim YH, Lee IJ. 2012. Endophytic fungi produce gibberellins and indoleacetic acid and promotes host-plant growth during stress. Molecules 17 (9): 10754-73. DOI: 10.3390/ molecules 170910754.

White TJ, Bruns TD, Lee SB, Taylor JW. 1990. Amplification and direct sequencing of fungal RNA genes for phylogenetics. In: Innis MA, Gelfand DH, Sninsky JJ, White TJ (eds) PCR protocols. Academic, San Diego.

Widowati T, Nuriyanah IB, Sukiman H. 2016. The potency of endophytic fungi isolated from taro (Colocasia esculenta (L.) Schott) as plant growth-promoting agent. In The 6th International Symposium for Sustainable Humanosphere, 15-16.

Wulandari RS, Suryantini R. 2019. Endophytic fungi in Paraserianthes falcataria: production of indole acetic acid. Microbiol Indones 13 (1): 16-24. DOI: 10.5454/mi.13.1.3.

Yuan ZL, Zhang CL, Lin FC. 2010. Role of diverse non-systemic fungal endophytes in plant performance and response to stress: progress and approaches. J Plant Growth Regul 29: 116-126. DOI: 10.1007/s00344-009-9112-9.

Zhang C, Zhang Y, Ding Z, Bai Y. 2019. Contribution of microbial interkingdom balance to plant health. Mol Plant 12 (2): 148-49. DOI: 10.1016/j.molp.2019.01.016.

Zheng YK, Miao CP, Chen HH, Huang FF, Xia YM, Chen YW, Zhao LX. 2017. Endophytic fungi harbored in Panax notoginseng: diversity and potential as biological control agents against host plant pathogens of root-rot disease. J Ginseng Res 41(3): 353-360.

Zhou LS, Tang K, Guo SX. 2018. The plant growth-promoting fungus (PGPF) Alternaria sp. a13 markedly enhances Salvia miltiorrhiza root growth and active ingredient accumulation under greenhouse and field conditions. Intl J Mol Sci: 19 (1): 1-19. DOI: 10.3390/ijms19010270. 